\title{
New Re-Os Ages from the Neoproterozoic Hecla Hoek Succession, Svalbard, Norway
}

ALEXIE MILLIKIN ${ }^{1}$, JUSTIN STRAUSS ${ }^{2}$, GALEN HALVERSON $^{3}$, KRISTIN BERGMANN ${ }^{4}$, NICHOLAS J. TOSCA $^{5}$, TIMOTHY GIBSON ${ }^{1}$, ROSS ANDERSON ${ }^{6}$ AND ALAN ROONEY ${ }^{1}$

${ }^{1}$ Yale University

${ }^{2}$ Dartmouth College

${ }^{3}$ McGill University

${ }^{4}$ Massachusetts Institute of Technology

${ }^{5}$ University of Cambridge

${ }^{6}$ University of Oxford

Presenting Author: alexie.millikin@yale.edu

The ca. 950-600 Ma lower and middle Hecla Hoek succession of Svalbard, Norway, which consists of the early-middle Tonian Veteranen Group, middle-late Tonian Akademikerbreen Group, and Cryogenian-Ediacaran Polarisbreen Group, represents one of the most complete and well preserved Neoproterozoic sedimentary successions worldwide. With diverse fossil assemblages, an extensive carbonate $\delta^{13} \mathrm{C}$ record, and sedimentary evidence for two distinct Cryogenian glaciations, this succession has the potential to yield profound insights into the Neoproterozoic Earth system; however, at present there are no radiometric age constraints for these strata. Current correlation schemes across northeastern Svalbard, as well as to Neoproterozoic successions globally, rely upon litho- and chemostratigraphic records.

Here we present the first direct radiometric age constraints from the Hecla Hoek succession. New Re-Os ages and geochemical data tightly constrain the age of Neoproterozoic glaciation in Svalbard and facilitate correlation of the negative carbon isotope excursion recorded in the Russøya member (Elbobreen Formation) with the pre-glacial Islay anomaly of the Callison Lake Formation (Windermere Supergroup) in Northwest Canada and the Tambien Group in Ethiopia. Vaseshaped microfossils from this same member can now also be allied to global records with pre-Cryogenian biostratigraphic significance. These results solidify global chemo- and biostratigraphic correlations for the late Tonian Period and lay the groundwork for assessing the synchroneity of biogeochemical cycle perturbations during this interval. In addition, these new age constraints provide a unique opportunity to construct a temporally-calibrated geochemical, biological, and geological framework to assess the timing and triggers of early eukaryotic evolution and the most extreme climatic changes in Earth history. 